\title{
Development and Validation of an Inductively Coupled Plasma Mass Spectrometry Method for Estimation of Elemental Impurities in Calcium Acetate Active Pharmaceutical Ingredient
}

\author{
R. K. CHAWLA*, S. N. K. R. GUDHANTI, U. KULANDAIVELU, S. P. PANDAAND R. R. ALAVALA \\ KL College of Pharmacy, Koneru Lakshmaiah Education Foundation, Vaddeswaram, Guntur, Andhra Pradesh 522502, India
}

Chawla et al.: Elemental Impurities Estimation in Calcium Acetate

\begin{abstract}
A sensitive and selective method has been developed and validated for the simultaneous quantitative estimation of aluminum, magnesium, potassium, strontium and sodium in calcium acetate active pharmaceutical ingredient by inductively coupled plasma mass spectrometry. Inductively coupled plasma mass spectrometry is an advanced technique which is capable of analyzing multiple elements simultaneously with high selectivity, sensitivity and much lower detection limit. The test sample was prepared with microwave assisted acid digestion and introduced into optimized instrumental parameters for use of a quadrupole based Agilent $\mathbf{7 8 0 0}$ inductively coupled plasma mass spectrometry instrument. Scandium is used as an internal standard in the study. The developed method was validated in terms of specificity, linearity, accuracy, precision, range, limit of detection, limit of quantitation and ruggedness. The results for recoveries of all elements were found between 85.3 to $103.9 \%$. The relative standard deviation for precision was within $15 \%$. Calibration plots were linear. The low relative standard deviation values and high recoveries of the method confirm the suitability of the method.
\end{abstract}

Key words: Calcium acetate, inductively coupled plasma mass spectrometry, microwave digestion, method validation

Calcium acetate is a calcium salt of acetic acid. Calcium ethanolate is the systematic name and its standard name is calcium acetate ${ }^{[1]}$. Calcium acetate is used to prevent high blood phosphate levels (called hyperphosphatemia) in patients who are on dialysis due to severe kidney disease. Dialysis lowers phosphate level from the blood, but it is difficult to remove enough quantity to keep the blood phosphate levels balanced. Decreasing phosphate levels in blood can help to keep the bones strong, prevent unsafe buildup of minerals in the body and prevent the risk of heart disease and strokes that result from high blood phosphate levels. Calcium acetate is a natural mineral that works by holding on to phosphate from the regular diet, so that phosphate can pass out of the body ${ }^{[2]}$. Calcium acetate is official in United States Pharmacopoeia ${ }^{[3]}$ and European Pharmacopoeia ${ }^{[4]}$, the monographs states to determine aluminum $(\mathrm{Al})$, magnesium $(\mathrm{Mg})$, potassium $(\mathrm{K})$, strontium $(\mathrm{Sr})$ and sodium $(\mathrm{Na})$ in calcium acetate active pharmaceutical ingredient (API) with

*Address for correspondence E-mail: rbchawla07@gmail.com specification given in Table 1. The analytical methods given in the monographs are fluorescence spectroscopy and color comparison methods for aluminum, atomic absorption spectrometry at $285.2 \mathrm{~nm}$ for magnesium, atomic absorption spectrometry at $766.5 \mathrm{~nm}$ for potassium, atomic absorption spectrometry at $460.7 \mathrm{~nm}$ for strontium and atomic absorption spectrometry at $589.0 \mathrm{~nm}$ for sodium. Hence for determination of stated elements, 5 different methods are required to use. The literature survey revealed that few methods are reported for determination of calcium in serum by atomic absorption spectroscopy ${ }^{[5,6]}$. Calcium determination by flame photometry is also reported ${ }^{[7,8]}$. Some methods are reported estimation of calcium by inductively

This is an open access article distributed under the terms of the Creative
Commons Attribution-NonCommercial-ShareAlike 3.0 License, which
allows others to remix, tweak, and build upon the work non-commercially,
as long as the author is credited and the new creations are licensed under
the identical terms

Accepted 18 August 2021 Revised 06 April 2021 Received 09 July 2020 Indian J Pharm Sci 2021;83(4):830-837 
TABLE 1: SPECIFICATIONS

\begin{tabular}{lcc}
\hline Element & $\begin{array}{c}\text { In percentage (\%) } \\
\text { (Not more than) }\end{array}$ & $\begin{array}{c}\text { In ppm (Not } \\
\text { more than) }\end{array}$ \\
\hline Aluminum (Al) & 0.0002 & 2 \\
Magnesium (Mg) & 0.05 & 500 \\
Potassium (K) & 0.05 & 500 \\
Strontium (Sr) & 0.05 & 500 \\
Sodium (Na) & 0.5 & 5000 \\
\hline
\end{tabular}

coupled plasma-mass spectroscopy (ICP-MS $)^{[9,10]}$. It was observed that there is no method available for quantitative estimation of stated 5 elements in calcium acetate API by ICP-MS. The purpose of this research article is to develop and validate a single method for simultaneous determination of stated 5 elements in calcium acetate API by ICP-MS.

\section{MATERIALS AND METHODS}

\section{Materials:}

Aluminum (1000 mg/l), magnesium (1000 mg/l), potassium (1000 mg/l), strontium $(1000 \mathrm{mg} / \mathrm{l})$, sodium (1000 mg/l) and scandium (1000 mg/l) inductively coupled plasma (ICP) standards were procured from Merck Millipore, India. Trace metal grade nitric acid $(67 \%)$ was procured from Fisher Scientific, India. De-ionized water used in standard and sample preparation was produced by Millipore Milli-Q water purification system. Calcium acetate samples were received as gift samples from Suven Life Sciences Limited, Hyderabad, India.

\section{Instrument and method:}

The method was developed and validated on Agilent Technologies, USA, 7800 series ICP-MS equipped with data acquisition and processing software Mass hunter. The samples were digested using a CEM Mars 5 microwave accelerated reaction system (MARS). The ICP-MS parameters were optimized and optimized conditions are shown in Table 2.

\section{Diluent preparation (Diluted nitric acid):}

Dilute $40.0 \mathrm{ml}$ of nitric acid to $1000 \mathrm{ml}$ with Milli-Q water.

\section{Standard stock preparation:}

Preparation of 0.5 parts per million (ppm) of aluminum standard (Stock-A solution): Transfer $0.1 \mathrm{ml}$ of $1000 \mathrm{ppm}$ standard of aluminum into a $10 \mathrm{ml}$ volumetric flask and make up to volume with diluent. This is $10 \mathrm{ppm}$ solution, from this solution transfer
$0.5 \mathrm{ml}$ into a $10 \mathrm{ml}$ volumetric flask and make up to volume with diluent.

Preparation of $125.0 \mathrm{ppm}$ each of magnesium, potassium and strontium standard (Stock-B solution): Transfer $1.25 \mathrm{ml}$ each of $1000 \mathrm{ppm}$ standard of magnesium, potassium and strontium into a $10 \mathrm{ml}$ volumetric flask and make up to volume with diluent.

Preparation of $500 \mathrm{ppm}$ of sodium standard (Stock-C solution): Transfer $5.0 \mathrm{ml}$ of $1000 \mathrm{ppm}$ of sodium standard into a $10 \mathrm{ml}$ volumetric flask and make up to volume with diluent.

Preparation of $10.0 \mathrm{ppm}$ of scandium (Stock-D solution/internal standard): Transfer $1.0 \mathrm{ml}$ of $1000 \mathrm{ppm}$ of scandium standard into a $10 \mathrm{ml}$ volumetric

TABLE 2: OPTIMIZED ICP-MS CONDITIONS OF THE DEVELOPED METHOD

\begin{tabular}{|c|c|}
\hline Contents & $\begin{array}{l}\text { Optimized ICP-MS } \\
\text { conditions }\end{array}$ \\
\hline RF power & 1550 Watts \\
\hline Plasma gas flow & $15 \mathrm{l} / \mathrm{min}$ \\
\hline Spray chamber temperature & $2^{\circ}$ \\
\hline Peak pattern & 3 points \\
\hline Helium gas flow & $4.3 \mathrm{ml} / \mathrm{min}$ \\
\hline Integration time & $0.3 \mathrm{~s}$ \\
\hline Tune mode & Helium gas \\
\hline Number of replicates & 3 \\
\hline Mass of aluminum & 27 (Analyte) \\
\hline Mass of magnesium & 24 (Analyte) \\
\hline Mass of potassium & 39 (Analyte) \\
\hline Mass of strontium & 88 (Analyte) \\
\hline Mass of sodium & 23 (Analyte) \\
\hline Mass of scandium & 45 (Internal standard) \\
\hline \multicolumn{2}{|l|}{ Before acquisition } \\
\hline Uptake speed (Nebulizer pump) & 0.30 rounds $/ \mathrm{s}$ \\
\hline Uptake time & $60 \mathrm{~s}$ \\
\hline Stabilization time & $45 \mathrm{~s}$ \\
\hline \multicolumn{2}{|l|}{ After acquisition (probe rinse) } \\
\hline Rinse speed (Nebulizer pump) & 0.30 rounds $/ \mathrm{s}$ \\
\hline Rinse at rinse port (sample) & $10 \mathrm{~s}$ \\
\hline Rinse at rinse port (standard) & $10 \mathrm{~s}$ \\
\hline Rinse vial 1 (4 \% nitric acid) & 1 \\
\hline Rinse speed (Nebulizer pump) & 0.30 rounds $/ \mathrm{s}$ \\
\hline Rinse at rinse vial (step 1) & $20 \mathrm{~s}$ \\
\hline Rinse at rinse port (step 1) & $20 \mathrm{~s}$ \\
\hline Rinse vial 2 (2 \% nitric acid) & 2 \\
\hline Rinse speed (Nebulizer pump) & 0.30 rounds $/ \mathrm{s}$ \\
\hline Rinse at rinse vial (step 2) & $20 \mathrm{~s}$ \\
\hline Rinse at rinse port (step 2) & $20 \mathrm{~s}$ \\
\hline Rinse vial 3 (milli-Q water) & 3 \\
\hline Rinse speed (Nebulizer pump) & 0.30 rounds $/ \mathrm{s}$ \\
\hline Rinse at rinse vial (step 3) & $20 \mathrm{~s}$ \\
\hline Rinse at rinse port (step 3) & $20 \mathrm{~s}$ \\
\hline
\end{tabular}

Note: RF-Radio frequency, ${ }^{\circ}$-temperature in degree centigrade 
flask and make up to volume with diluent. This is $100 \mathrm{ppm}$ solution, from this solution transfer $1.0 \mathrm{ml}$ into a $10 \mathrm{ml}$ volumetric flask and make up to volume with diluent.

\section{Preparation of linearity standard solutions:}

Calibration blank: Transfer $0.1 \mathrm{ml}$ of stock-D solution into $10 \mathrm{ml}$ volumetric flask and make up to volume with diluent.

Calibration standard solution-1 (Aluminum 0.005 ppm, magnesium $1.25 \mathrm{ppm}$, potassium $1.25 \mathrm{ppm}$, strontium $1.25 \mathrm{ppm}$ and sodium $12.5 \mathrm{ppm}$ ): Transfer $0.1 \mathrm{ml}$ of stock-A solution, $0.1 \mathrm{ml}$ of stock-B solution, $0.25 \mathrm{ml}$ of stock-C solution and $0.1 \mathrm{ml}$ of stock-D solution into $10 \mathrm{ml}$ volumetric flask and make up to volume with diluent.

Calibration standard solution-2 (Aluminum $0.01 \mathrm{ppm}$, magnesium $2.5 \mathrm{ppm}$, potassium $2.5 \mathrm{ppm}$, strontium $2.5 \mathrm{ppm}$ and sodium $25.0 \mathrm{ppm}$ ): Transfer $0.2 \mathrm{ml}$ of stock-A solution, $0.2 \mathrm{ml}$ of stock-B solution, $0.5 \mathrm{ml}$ of stock-C solution and $0.1 \mathrm{ml}$ of stock-D solution into $10 \mathrm{ml}$ volumetric flask and make up to volume with diluent.

Calibration standard solution-3 (Aluminum $0.02 \mathrm{ppm}$, magnesium $5.0 \mathrm{ppm}$, potassium $5.0 \mathrm{ppm}$, strontium $5.0 \mathrm{ppm}$ and sodium $50.0 \mathrm{ppm}$ ): Transfer $0.4 \mathrm{ml}$ of stock-A solution, $0.4 \mathrm{ml}$ of stock-B solution, $1.0 \mathrm{ml}$ of stock-C solution and $0.1 \mathrm{ml}$ of stock-D solution in to $10 \mathrm{ml}$ volumetric flask and make up to volume with diluent.

Calibration standard solution-4 (Aluminum 0.03 ppm, magnesium 7.5 ppm, potassium 7.5 ppm, strontium $7.5 \mathrm{ppm}$ and sodium $75.0 \mathrm{ppm}$ ): Transfer $0.6 \mathrm{ml}$ of stock-A solution, $0.6 \mathrm{ml}$ of stock-B solution, $1.5 \mathrm{ml}$ of stock-C solution and $0.1 \mathrm{ml}$ of stock-D solution into $10 \mathrm{ml}$ volumetric flask and make up to volume with diluent.

Calibration standard solution-5 (Aluminum 0.04 ppm, magnesium 10.0 ppm, potassium 10.0 ppm, strontium $10.0 \mathrm{ppm}$ and sodium $100.0 \mathrm{ppm})$ : Transfer $0.8 \mathrm{ml}$ of stock-A solution, $0.8 \mathrm{ml}$ of stock-B solution, $2.0 \mathrm{ml}$ of stock-C solution and $0.1 \mathrm{ml}$ of stock-D solution into $10 \mathrm{ml}$ volumetric flask and make up to volume with diluent.

Calibration standard solution-6 (Aluminum $0.05 \mathrm{ppm}$, magnesium $12.5 \mathrm{ppm}$, potassium 12.5 ppm, strontium $12.5 \mathrm{ppm}$ and sodium $125.0 \mathrm{ppm}$ ): Transfer $1.0 \mathrm{ml}$ of stock-A solution, $1.0 \mathrm{ml}$ of stock-B solution, $2.5 \mathrm{ml}$ of stock-C solution and $0.1 \mathrm{ml}$ of stock-D solution into $10 \mathrm{ml}$ volumetric flask and make up to volume with diluent.

Preparation of standard check solution (Aluminum $0.02 \mathrm{ppm}$, magnesium $5.0 \mathrm{ppm}$, potassium $5.0 \mathrm{ppm}$, strontium 5.0 ppm and sodium $50.0 \mathrm{ppm}$ ): Transfer $0.4 \mathrm{ml}$ of stock-A solution, $0.4 \mathrm{ml}$ of stock-B solution, $1.0 \mathrm{ml}$ of stock-C solution and $0.1 \mathrm{ml}$ of stock-D solution into $10 \mathrm{ml}$ volumetric flask and make up to volume with diluent.

\section{Test sample preparation:}

Weigh and transfer about $100 \mathrm{mg}$ of calcium acetate API test sample into a Teflon digestion tube and transfer $0.1 \mathrm{ml}$ of stock-D solution, add $1 \mathrm{ml}$ of nitric acid and $2 \mathrm{ml}$ of diluent. Fix the tube in microwave digester and start the microwaving cycle with $1200 \mathrm{~W}$ power, $150^{\circ}$ temperature, $200 \mathrm{psi}$ pressure, ramp $20 \mathrm{~min}$ and hold time $15 \mathrm{~min}$. After completion of digestion cycle, carefully transfer the solution into $10 \mathrm{ml}$ volumetric flask. Rinse the tube with $2 \mathrm{ml}$ of diluent and transfer into volumetric flask, make up to volume with diluent.

\section{Sample blank preparation:}

Proceed as directed in test sample preparation without taking calcium acetate test API.

Procedure: Aspirate one time each of calibration standard solutions and develop a calibration curve and standard check solution of $\mathrm{Al}, \mathrm{Mg}, \mathrm{K}, \mathrm{Sr}$ and $\mathrm{Na}$. Aspirate sample blank and sample preparation into the instrument and calculate the $\mathrm{Al}, \mathrm{Mg}, \mathrm{K}, \mathrm{Sr}$ and $\mathrm{Na}$ content respectively.

Calculations: Sample content (in \%)=Instrument reading (in ppm)/Sample weight (in g) $\times 10 / 10000$

Sample content (in ppm)=Instrument reading (in ppm)/ Sample weight (in $\mathrm{g}) \times 10$

Acceptance criteria for system suitability:

Correlation coefficient for aluminum, magnesium, potassium, strontium and sodium should be not less than 0.99 from calibration standard solutions.

Concentration of aluminum, magnesium, potassium, strontium and sodium in standard check solution should not vary by $\pm 20 \%$ of actual concentration.

\section{Method validation:}

The developed method was validated as per International Conference on Harmonization (ICH) Q2 (R1) 
guidelines ${ }^{[11]}$, United States Pharmacopoeia general chapter $<233>^{[12]}$ and United States Pharmacopoeia general chapter $<1225>^{[13]}$.

System suitability: System suitability was checked as per the developed method and accordance with United States Pharmacopoeia general chapter $<233>{ }^{[12]}$. Aspirated one time each of calibration standard solution 1 to 6 and standard check solution into ICPMS instrument and evaluated the correlation coefficient and concentration in standard check for aluminum, magnesium, potassium, strontium and sodium as per the system suitability acceptance criteria.

Specificity: The procedure must be able to unequivocally assess each target element in the presence of components that may be expected to be present, including matrix components. Blank interference was performed to establish the non-interference or extent of interference of blank in estimation of elements by ICPMS, as per the developed procedure, aspirated blank and standard solutions. Blank interference was evaluated by measuring percentage (\%) interference of 10 replicate injections of blank injections response, with respect to calibration standard solution-1 response. Being the method is by mass spectrometry and each element is analyzed by its individual respective mass weight, the interference of elements within the method and other elements present in blank and matrix is negligible. The acceptance criteria were set as the interference of calibration blank of aluminum, magnesium, potassium, strontium and sodium should be not more than $20 \%$ response (counts per seconds (cps)) of the calibration standard solution-1.

Precision: Precision of the development method was evaluated by aspirating 6 independent samples of material under test (taken from the same lot) spiked with reference materials for the target elements at the specification level. As per the test method, prepared and aspirated 6 independent preparations of $100 \%$ spiked sample solutions and evaluated the precision by calculating target element content and percentage relative standard deviation (\% RSD) for 6 preparations of spiked sample solutions. Intermediate precision (IP) of the method was also evaluated using different analyst on different day by aspirating 6 independent preparations of $100 \%$ spiked sample solutions prepared as same for precision. The acceptance criteria for individual precision \% RSD was not more than 20.0 and for 12 preparation results was not more than 25.0.

Accuracy (Recovery): The accuracy of an analytical procedure is the closeness of test results obtained by that procedure to the true value. Recovery study was performed to evaluate the accuracy of the method by spiking method. Recovery study was done by spiking the target elements into test sample in the concentration of $25 \%, 50 \%, 100 \%, 150 \%$ and $250 \%$ level of the proposed concentration. The test samples were prepared in triplicate for $50 \%, 100 \%$ and $150 \%$ level and 6 preparations for $25 \%$ and $200 \%$. Aspirated the prepared spiked samples in the proposed experimental conditions and percentage (\%) recoveries of target elements were calculated for all the levels. The acceptance criterion for $\%$ recovery for aluminum, magnesium, potassium, strontium and sodium should be $70 \%$ to $150 \%$ for each individual spike level and \% RSD for 6 recovery results at $25 \%$ and $250 \%$ was not more than 15.0.

\section{Limit of detection (LOD) and limit of quantitation}

(LOQ): LOD is the lowest amount of analyte in sample that can be detected, but not necessarily quantifiable and LOQ is the lowest amount of analyte that can be quantitated with acceptable accuracy, precision, under the stated experimental conditions. The LOD and LOQ were established by the standard deviation (SD) of the response and the slope method using calibration curve. The LOD and LOQ were determined by aspirating known concentrations of aluminum, magnesium, potassium, strontium and sodium elements from $10 \%$ to $100 \%$ of the target concentration under the stated experimental conditions. The LOD and LOQ were calculated using the formula based on the SD of the response and the slope. LOD and LOQ were calculated by using equations, $\mathrm{LOD}=3.3 \times \mathrm{SD} / \mathrm{S}$ and $\mathrm{LOQ}=10 \times \mathrm{SD} / \mathrm{S}$, where $\mathrm{SD}=$ standard deviation, $\mathrm{S}=$ slope of the calibration curve.

Linearity: Linearity of the method was established for aluminum, magnesium, potassium, strontium and sodium elements from $25 \%$ to $250 \%$ of the proposed concentration using 6 calibration levels $(25,50,100$, 150, 200 and $250 \%$ ). The reference standards were used to prepare calibration levels. The calibration curves were plotted for all elements as concentration of level verses response. The result of linearity was evaluated by regression analysis.

Solution stability: Solution stability was established for calibration standards and test sample preparations. Bench-top (ambient temperature) stability was established by aspirating standards and test sample spiked at $100 \%$ level at regular interval for $2 \mathrm{~d}$. Solution stability was established by calculating similarity factor 
for standard against fresh standard and percentage element content difference for test sample from initial value. The acceptance criteria for solution stability were considered $\pm 20 \%$ relative of initial concentration/ content.

\section{RESULTS AND DISCUSSION}

System suitability of the method was evaluated by means of correlation coefficient of calibration standard solution and concentration in standard check for aluminum, magnesium, potassium, strontium and sodium. The system suitability results were found within the acceptance criteria. The results are presented in Table 3.

The specificity was performed to check blank interference and evaluated the percentage interference for aluminum, magnesium, potassium, strontium and sodium. The result shows it meets the criteria of not more than $20 \%$ response (cps) interference of the calibration standard solution-1. The results are presented in Table 4.

\section{TABLE 3: SYSTEM SUITABILITY RESULTS}

\begin{tabular}{lcc}
\hline System suitability parameter & Element & Result \\
\hline & Aluminum & 0.9999 \\
& Magnesium & 1.0000 \\
Correlation coefficient $(r)$ & Potassium & 0.9999 \\
& Strontium & 0.9999 \\
& Sodium & 1.0000 \\
& Aluminum & 1.65 \\
Concentration variation in & Magnesium & -0.55 \\
standard check solution & Potassium & 1.95 \\
& Strontium & -0.30 \\
& Sodium & -1.85 \\
\hline
\end{tabular}

Precision was evaluated by aspirating 6 independent samples spiked with reference materials for the target elements at the specification level (i.e. $100 \%$ ). \% RSD of aluminum, magnesium, potassium, strontium and sodium $(\mathrm{n}=6)$ was found to be $3.1,1.7,1.6,1.4$ and 0.5 respectively. For IP, it was found to be 2.8, 2.2, 2.4, 2.0 and 0.7 respectively. \% RSD of precision and IP $(n=12)$ was found to be $2.8,2.0,2.1,2.4$ and 0.6 respectively. The results were found within acceptance criteria for precision of the developed method. The results of precision are compiled in Table 5.

The accuracy was evaluated by calculating the recoveries at $25 \%, 50 \%, 100 \%, 150 \%$ and $250 \%$ level of the proposed concentration. The individual recoveries for all 5 elements at all levels were found between 85.3 to $103.9 \%$ and the mean percentage (\%) recoveries were found between 91.2 to $100.8 \%$. $\%$ RSD for 6 recovery results (precision) at $25 \%$ and $250 \%$ were found between 1.0 to 7.6 . The recoveries were found within the acceptance criteria and method found to be accurate. The results of accuracy are presented in Table 6 and Table 7.

The LOD and LOQ were determined by aspirating known concentrations of aluminum, magnesium, potassium, strontium and sodium elements from $10 \%$ to $100 \%$ of the target concentration and the LOQ were found to be $0.31 \mathrm{ppm}, 1.56 \mathrm{ppm}, 1.83 \mathrm{ppm}$, $0.12 \mathrm{ppm}$ and $3.65 \mathrm{ppm}$ with respect to test concentration respectively. The determined LOQ values are much below than the $25 \%$ of the targeted concentrations. The LOD and LOQ values are presented in Table 8.

Linearity of the method was established for aluminum, magnesium, potassium, strontium and sodium elements

TABLE 4: SPECIFICITY-CALIBRATION BLANK INTERFERENCE

\begin{tabular}{|c|c|c|c|c|c|}
\hline \multirow{2}{*}{ Aspiration } & \multicolumn{5}{|c|}{ Calibration blank response (cps) } \\
\hline & $\mathrm{Al}$ & $\mathrm{Mg}$ & $\mathrm{K}$ & $\mathrm{Sr}$ & $\mathrm{Na}$ \\
\hline Calibration blank-1 & 15.56 & 276.68 & 335.69 & 114.45 & 1881.22 \\
\hline Calibration blank-2 & 25.56 & 488.92 & 335.35 & 2058.17 & 2083.22 \\
\hline Calibration blank-3 & 34.44 & 307.79 & 327.74 & 130.00 & 1662.71 \\
\hline Calibration blank-4 & 30.00 & 348.91 & 325.19 & 116.67 & 1610.32 \\
\hline Calibration blank-5 & 27.78 & 452.25 & 334.62 & 193.34 & 1659.09 \\
\hline Calibration blank-6 & 10.00 & 461.13 & 331.88 & 132.23 & 1595.30 \\
\hline Calibration blank-7 & 21.11 & 500.03 & 341.87 & 122.23 & 1613.15 \\
\hline Calibration blank-8 & 16.67 & 494.47 & 330.15 & 130.01 & 1604.60 \\
\hline Calibration blank-9 & 21.11 & 568.92 & 327.49 & 128.89 & 1562.59 \\
\hline Calibration blank-10 & 17.78 & 604.48 & 320.68 & 134.45 & 1528.56 \\
\hline Mean $(n=10)$ & 22.00 & 450.36 & 33102.07 & 326.04 & 16802.48 \\
\hline Calibration standard solution-1 & 2518.90 & 285816.37 & 262155.87 & 3317994.57 & 5515151.45 \\
\hline $20 \%$ response (cps) of calibration standard solution- 1 & 503.78 & 57163.27 & 52431.17 & 663598.91 & 1103030.29 \\
\hline
\end{tabular}

Note: Al-Aluminum; Mg-Magnesium; K-Potassium; Sr-Strontium and $\mathrm{Na}$-Sodium 
TABLE 5: PRECISION RESULTS

\begin{tabular}{|c|c|c|c|c|c|c|c|c|c|c|}
\hline \multirow{3}{*}{$\begin{array}{l}\text { Spiked test } \\
\text { sample }\end{array}$} & \multicolumn{10}{|c|}{ Content (\%) } \\
\hline & MP & IP & MP & IP & MP & IP & MP & IP & MP & IP \\
\hline & $\mathrm{Al}$ & Al & $\mathrm{Mg}$ & $\mathrm{Mg}$ & K & $\mathrm{K}$ & $\mathrm{Sr}$ & $\mathrm{Sr}$ & $\mathrm{Na}$ & $\mathrm{Na}$ \\
\hline 01 & 0.0001924 & 0.0002019 & 0.049 & 0.047 & 0.047 & 0.048 & 0.053 & 0.051 & 0.482 & 0.490 \\
\hline 02 & 0.0001872 & 0.0001989 & 0.048 & 0.049 & 0.048 & 0.047 & 0.054 & 0.052 & 0.488 & 0.486 \\
\hline 03 & 0.0001979 & 0.0001939 & 0.050 & 0.050 & 0.046 & 0.049 & 0.053 & 0.05 & 0.489 & 0.492 \\
\hline 04 & 0.0002021 & 0.0001892 & 0.049 & 0.048 & 0.047 & 0.046 & 0.052 & 0.051 & 0.486 & 0.488 \\
\hline 05 & 0.0001996 & 0.0002031 & 0.050 & 0.049 & 0.047 & 0.048 & 0.054 & 0.052 & 0.484 & 0.483 \\
\hline 06 & 0.0002029 & 0.0001927 & 0.050 & 0.048 & 0.048 & 0.049 & 0.053 & 0.053 & 0.487 & 0.484 \\
\hline $\begin{array}{l}\text { Mean } \\
(\mathrm{n}=6)\end{array}$ & 0.0001970 & 0.0001966 & 0.049 & 0.049 & 0.047 & 0.048 & 0.053 & 0.052 & 0.486 & 0.487 \\
\hline$\%$ RSD $(n=6)$ & 3.1 & 2.8 & 1.7 & 2.2 & 1.6 & 2.4 & 1.4 & 2.0 & 0.5 & 0.7 \\
\hline$\% \operatorname{RSD}(n=12)$ & \multicolumn{2}{|c|}{2.8} & \multicolumn{2}{|c|}{2.0} & \multicolumn{2}{|c|}{2.1} & \multicolumn{2}{|c|}{2.4} & \multicolumn{2}{|c|}{0.6} \\
\hline
\end{tabular}

Note: MP-Method precision; IP-Intermediate precision; Al-Aluminum; Mg-Magnesium; K-Potassium; Sr-Strontium; Na-Sodium; \% RSD-\% Relative standard deviation, $(n=6)$ is number of test samples=6; $(n=12)$ is number of test samples=12

TABLE 6: ACCURACY RESULTS

\begin{tabular}{|c|c|c|c|c|c|c|c|c|c|c|}
\hline \multirow{2}{*}{$\begin{array}{l}\text { Accuracy } \\
\text { Recovery level }\end{array}$} & \multicolumn{2}{|c|}{ Aluminum } & \multicolumn{2}{|c|}{ Magnesium } & \multicolumn{2}{|c|}{ Potassium } & \multicolumn{2}{|c|}{ Strontium } & \multicolumn{2}{|c|}{ Sodium } \\
\hline & R (\%) & $\begin{array}{c}\text { Mean } \\
(\%)\end{array}$ & R (\%) & $\begin{array}{c}\text { Mean } \\
\text { (\%) }\end{array}$ & R (\%) & Mean (\%) & R (\%) & $\begin{array}{c}\text { Mean } \\
\text { (\%) }\end{array}$ & R (\%) & Mean (\%) \\
\hline $25 \%$ sample-1 & 103.5 & \multirow{6}{*}{$\begin{array}{c}93.2 \\
(n=6)\end{array}$} & 88.7 & \multirow{6}{*}{$\begin{array}{c}91.3 \\
(n=6)\end{array}$} & 92.4 & \multirow{6}{*}{$\begin{array}{c}91.2 \\
(n=6)\end{array}$} & 88.5 & \multirow{4}{*}{$\begin{array}{l}92.0 \\
(n=6)\end{array}$} & 93.4 & \multirow{6}{*}{$\begin{array}{l}96.2 \\
(n=6)\end{array}$} \\
\hline $25 \%$ sample- 2 & 93.3 & & 96.6 & & 91.4 & & 93.2 & & 96.8 & \\
\hline $25 \%$ sample-3 & 85.3 & & 91.5 & & 87.3 & & 90.8 & & 94.7 & \\
\hline $25 \%$ sample- 4 & 96.4 & & 93.9 & & 96.2 & & 92.7 & & 97.9 & \\
\hline $25 \%$ sample-5 & 89.6 & & 90.7 & & 88.4 & & 91.3 & & 98.3 & \\
\hline $25 \%$ sample- 6 & 91.1 & & 86.5 & & 91.4 & & 95.4 & & 95.9 & \\
\hline $50 \%$ sample-1 & 94.5 & \multirow{3}{*}{$\begin{array}{l}96.7 \\
(n=3)\end{array}$} & 98.2 & \multirow{3}{*}{$\begin{array}{c}97.5 \\
(n=3)\end{array}$} & 96.4 & \multirow{3}{*}{$\begin{array}{c}95.4 \\
(n=3)\end{array}$} & 95.6 & \multirow{3}{*}{$\begin{array}{l}96.5 \\
(n=3)\end{array}$} & 98.5 & \multirow{3}{*}{$\begin{array}{c}98.4 \\
(n=3)\end{array}$} \\
\hline 50 \% sample-2 & 98.7 & & 96.3 & & 94.6 & & 96.5 & & 99.7 & \\
\hline $50 \%$ sample- 3 & 96.8 & & 97.9 & & 95.2 & & 97.5 & & 96.9 & \\
\hline 100 \% sample-1 & 97.3 & \multirow{3}{*}{$\begin{array}{l}97.7 \\
(n=3)\end{array}$} & 99.3 & \multirow{3}{*}{$\begin{array}{c}98.5 \\
(n=3)\end{array}$} & 97.2 & \multirow{3}{*}{$\begin{array}{c}98.2 \\
(n=3)\end{array}$} & 99.4 & \multirow{3}{*}{$\begin{array}{c}99.4 \\
(n=3)\end{array}$} & 100.5 & \multirow{3}{*}{$\begin{array}{l}100.7 \\
(n=3)\end{array}$} \\
\hline 100 \% sample-2 & 98.1 & & 98.6 & & 99.1 & & 100.5 & & 103.1 & \\
\hline $100 \%$ sample-3 & 97.7 & & 97.7 & & 98.2 & & 98.4 & & 98.4 & \\
\hline 150 \% sample-1 & 99.3 & \multirow{3}{*}{$\begin{array}{c}98.6 \\
(n=3)\end{array}$} & 99.8 & \multirow{3}{*}{$\begin{array}{l}100.5 \\
(n=3)\end{array}$} & 102.1 & \multirow{3}{*}{$\begin{array}{l}100.3 \\
(n=3)\end{array}$} & 103.9 & \multirow{3}{*}{$\begin{array}{l}100.5 \\
(n=3)\end{array}$} & 103.1 & \multirow{3}{*}{$\begin{array}{l}100.3 \\
(n=3)\end{array}$} \\
\hline 150 \% sample-2 & 98.6 & & 103.0 & & 100.3 & & 98.3 & & 99.5 & \\
\hline 150 \% sample-3 & 97.9 & & 98.6 & & 98.4 & & 99.4 & & 98.2 & \\
\hline 250 \% sample-1 & 100.9 & \multirow{6}{*}{$\begin{array}{c}99.3 \\
(n=6)\end{array}$} & 99.0 & \multirow{6}{*}{$\begin{array}{l}100.5 \\
(n=6)\end{array}$} & 100.5 & \multirow{6}{*}{$\begin{array}{l}100.1 \\
(n=6)\end{array}$} & 102.8 & \multirow{6}{*}{$\begin{array}{c}99.7 \\
(n=6)\end{array}$} & 102.4 & \multirow{6}{*}{$\begin{array}{l}100.8 \\
(n=6)\end{array}$} \\
\hline 250 \% sample-2 & 99.7 & & 102.4 & & 99.1 & & 101.5 & & 101.3 & \\
\hline $250 \%$ sample-3 & 99.4 & & 100.3 & & 97.3 & & 99.1 & & 99.8 & \\
\hline $250 \%$ sample-4 & 98.7 & & 98.5 & & 101.5 & & 98.3 & & 97.9 & \\
\hline $250 \%$ sample-5 & 98.2 & & 99.9 & & 103.5 & & 97.2 & & 102.8 & \\
\hline $250 \%$ sample-6 & 98.9 & & 102.7 & & 98.6 & & 99.4 & & 100.8 & \\
\hline
\end{tabular}

Note: R=Recovery

from $25 \%$ to $250 \%$ of the proposed concentration using 6 calibration levels $(25,50,100,150,200$ and $250 \%$ ) and the correlation coefficient $\left(\mathrm{r}^{2}\right)$ were found to be $0.9997,0.9998,0.9997,0.9997$ and 0.9997 respectively. The linearity data is presented in Table 9.

Solution stability of calibration standards and test sample preparations were established on bench-top (ambient temperature) and were found stabile for $2 \mathrm{~d}$. The acceptance criteria of $\pm 20 \%$ relative of initial concentration/content were found within the limit.

A single method was developed for simultaneous determination of aluminum, magnesium, potassium, strontium and sodium elements in calcium acetate API and validated. The proposed method is innovative, 
www.ijpsonline.com

TABLE 7: PRECISION AT $25 \%$ AND $250 \%$ RESULTS

\begin{tabular}{|c|c|c|c|c|c|c|c|c|c|c|}
\hline \multirow{2}{*}{$\frac{\text { Precision }}{\text { Recovery level }}$} & \multicolumn{2}{|c|}{ Aluminum } & \multicolumn{2}{|c|}{ Magnesium } & \multicolumn{2}{|c|}{ Potassium } & \multicolumn{2}{|c|}{ Strontium } & \multicolumn{2}{|c|}{ Sodium } \\
\hline & R (\%) & $\begin{array}{c}\text { Mean (\%) } \\
(n=6)\end{array}$ & R (\%) & $\begin{array}{c}\text { Mean (\%) } \\
(n=6)\end{array}$ & R (\%) & $\begin{array}{c}\text { Mean (\%) } \\
(n=6)\end{array}$ & $\mathrm{R}(\%)$ & $\begin{array}{c}\text { Mean (\%) } \\
(n=6)\end{array}$ & $\mathrm{R}(\%)$ & $\begin{array}{c}\text { Mean (\%) } \\
(n=6)\end{array}$ \\
\hline $25 \%$ sample- 1 & 103.5 & & 88.7 & & 92.4 & & 88.5 & & 93.4 & \\
\hline $25 \%$ sample-2 & 93.3 & & 96.6 & & 91.4 & & 93.2 & & 96.8 & \\
\hline $25 \%$ sample- 3 & 85.3 & & 91.5 & & 87.3 & & 90.8 & & 94.7 & \\
\hline $25 \%$ sample-4 & 96.4 & 93.2 & 93.9 & 91.3 & 96.2 & 91.2 & 92.7 & 92.0 & 97.9 & 96.2 \\
\hline $25 \%$ sample-5 & 89.6 & & 90.7 & & 88.4 & & 91.3 & & 98.3 & \\
\hline $25 \%$ sample- 6 & 91.1 & & 86.5 & & 91.4 & & 95.4 & & 95.9 & \\
\hline$\%$ RSD & 6.7 & & 4.0 & & 3.5 & & 2.6 & & 2.0 & \\
\hline $250 \%$ sample-1 & 100.9 & & 99.0 & & 100.5 & & 102.8 & & 102.4 & \\
\hline $250 \%$ sample-2 & 99.7 & & 102.4 & & 99.1 & & 101.5 & & 101.3 & \\
\hline $250 \%$ sample-3 & 99.4 & & 100.3 & & 97.3 & & 99.1 & & 99.8 & \\
\hline $250 \%$ sample-4 & 98.7 & 99.3 & 98.5 & 100.5 & 101.5 & 100.1 & 98.3 & 99.7 & 97.9 & 100.8 \\
\hline $250 \%$ sample-5 & 98.2 & & 99.9 & & 103.5 & & 97.2 & & 102.8 & \\
\hline $250 \%$ sample-6 & 98.9 & & 102.7 & & 98.6 & & 99.4 & & 100.8 & \\
\hline$\%$ RSD & 1.0 & & 1.7 & & 2.2 & & 2.1 & & 1.8 & \\
\hline
\end{tabular}

Note: R-Recovery; \% RSD-\% Relative standard deviation

TABLE 8: LOD AND LOQ

\begin{tabular}{lcc}
\hline \multirow{2}{*}{ Element } & \multicolumn{2}{c}{ In ppm, with respect to test concentration } \\
\cline { 2 - 3 } & LOD & LOQ \\
\hline Aluminum (Al) & 0.10 & 0.31 \\
Magnesium $(\mathrm{Mg})$ & 0.51 & 1.56 \\
Potassium $(\mathrm{K})$ & 0.60 & 1.83 \\
Strontium $(\mathrm{Sr})$ & 0.04 & 0.12 \\
Sodium $(\mathrm{Na})$ & 1.20 & 3.65 \\
\hline
\end{tabular}

TABLE 9: LINEARITY

\begin{tabular}{lccccc}
\hline Linearity & Aluminum & Magnesium & Potassium & Strontium & Sodium \\
\hline Linearity level & Response (cps) & Response (cps) & Response (cps) & Response (cps) & Response (cps) \\
\hline Linearity level-1 (25\%) & 2400.28 & 337012.15 & 337166.43 & 4156070.98 & 6562823.03 \\
Linearity level-2 (50\%) & 4690.92 & 672397.66 & 637765.24 & 8224560.02 & 13081520.64 \\
Linearity level-3 (100\%) & 9093.13 & 1337954.73 & 1239875.34 & 16433392.67 & 26083381.00 \\
Linearity level-4 (150\%) & 13840.30 & 2043741.97 & 1943350.14 & 25267466.57 & 39438009.69 \\
Linearity level-5 (200 \%) & 18327.54 & 2809319.89 & 2596602.72 & 34741596.70 & 54786090.85 \\
Linearity level-6 (250 \%) & 23482.87 & 3470405.05 & 3208190.71 & 43546251.02 & 67554352.88 \\
Slope & 4651.98 & 28066268.94 & 25715479.14 & 348576772.2 & 54356746.49 \\
Y-intercept & -45.11 & -34141.29 & -5335.54 & -654029.99 & -696562.75 \\
Correlation coefficient $(r)$ & 0.9997 & 0.9998 & 0.9997 & 0.9997 & 0.9997 \\
\hline
\end{tabular}

selective, simple, accurate and rugged which can be used for routine analysis in quality control and research laboratory.

\section{Acknowledgements:}

The authors express their thanks to Suven Life Sciences Limited, Hyderabad for support and providing the research facility to carrying out the work.

\section{Conflict of interests:}

The authors declare no conflict of interest.

\section{REFERENCES}

1. Calcium acetate. Wikipedia: The free encyclopedia; 2020.

2. Calcium acetate. WebMD; 2020.

3. The United States Pharmacopeia 2018: USP 41; The national formulary: NF 36. Official monographs, calcium acetate. The 
United States Pharmacopeial Convention 2018. p. 627-9.

4. The European Pharmacopoeia 9.0, Council of Europe (2017), Official monographs, calcium acetate 2017. p. 1910-1.

5. Sudhakar K, Sujatha M, Babu SR, Padmavathi P, Reddy PP. Serum calcium levels in patients with essential hypertension and their first degree relatives. Indian $\mathrm{J}$ Clin Biochem 2004;19(1):21-3.

6. Maqueda C, Morillo E. Determination of calcium by atomicabsorption spectrometry in samples dissolved by acid mixtures. Fresenius J Anal Chem 1990;338(3):253-4.

7. Baker RW. The determination of calcium in serum by flame photometry. Biochem J 1955;59(4):566-71.

8. The simple Flame Photometric determination of calcium. Bibby Scientific, Protocol: P05-011A; 2020.

9. Chen Z, Griffin IJ, Kriseman YL, Liang LK, Abrams SA. Inductively coupled plasma mass spectrometric analysis of calcium isotopes in human serum: a low-sample-volume acid- equilibration method. Clin Chem 2003;49(12):2050-5.

10. Lee A, Yang V, Hsu J, Wu E, Shih R, Mizobuchi K. Ultratrace measurement of calcium in ultrapure water using the Agilent 8800 triple quadrupole ICP-MS. Agilent Technologies, Tokyo, Japan; 2012.

11. International Conference on Harmonization, Q2 (R1). Validation of analytical procedure: Text and Methodology. Step-4 Consensus Guideline, International conference on harmonisation of technical requirements for registration of pharmaceuticals for human use. Geneva 1994.

12. The United States Pharmacopoeia 41, the National Formulary 36. General Chapter $<233>$ Elemental Impurities-Procedures. United States Pharmacopeia Convention; 2018.

13. The United States Pharmacopoeia 41, the National Formulary 36. General Chapter $<1225>$ Validation of Compendial Procedures, United States Pharmacopeia Convention; 2018. 